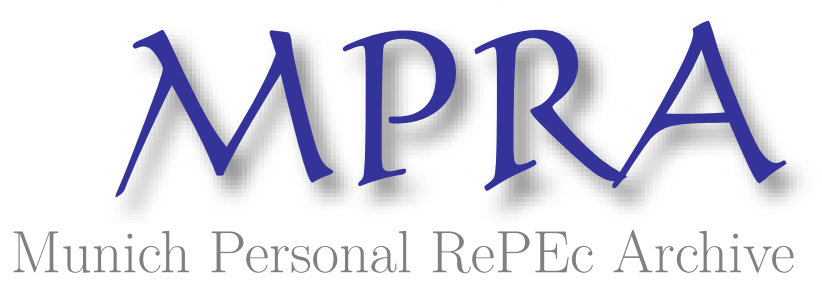

\title{
Market for Corporate Control and Contractual Buyout (CoBO): A New "Collective Ownership-and-Administrative" Strategy
}

Reddy, Kotapati Srinivasa

Indian Institute of Technology (IIT) Roorkee

2015

Online at https://mpra.ub.uni-muenchen.de/63937/

MPRA Paper No. 63937, posted 28 Apr 2015 06:31 UTC 
Market for Corporate Control and Contractual Buyout (CoBO): A New

"Collective Ownership-and-Administrative" Strategy

\author{
Kotapati Srinivasa Reddy \\ Indian Institute of Technology (IIT) Roorkee, \\ Department of Management Studies, Roorkee - 247667, Uttarakhand (Republic of India). \\ E-mail: cssrinivasareddy@gmail.com
}

2015

Paper in Progress 


\title{
Market for Corporate Control and Contractual Buyout (CoBO): A New \\ “Collective Ownership-and-Administrative" Strategy
}

\begin{abstract}
Contractual buyout $(\mathrm{CoBO})$ is a new "collective ownership and joint administrative strategy", which gives an opportunity to buy a target firm in the given period when the given contract ends between acquirer, target firm, and financier. It is a takeover defensive method and tends to avail tax advantage via entering $\mathrm{CoBO}$ deal. In particular, it would be efficient inorganic magnetic for international venture capitalists and private equity firms while entering foreign markets. More specifically, CoBO is likely a concept of Dating-beforeMerging and it would be the better model for cross-border mergers and acquisitions integration strategy. The explored $\mathrm{CoBO}$ propositions may be useful in various implications such as information symmetry and administrative changes, employment and employee role, operating performance and financial arrangement, tax savings, choice of market entry strategy, integration strategy, and government and policy makers. We recommend the developed country investors choose $\mathrm{CoBO}$ as investment vehicle to avail the competent business opportunities in both emerging and budding economies.
\end{abstract}

JEL Classification: G34; G38; M48

Keywords: Contractual buyout; Collective ownership; Inorganic strategy; Leveraged buyout; Market for corporate control; Mergers and acquisitions; Strategic alliances, Takeovers. 
Why are takeovers necessary to shrink declining industries? The easy answers such as managers do not want to lose their jobs' are not satisfactory. A CEO with a golden parachute might end up richer by closing redundant plants than by keeping them open.

- Lambrecht and Myers (2007: 810)

\section{INTRODUCTION}

The splendor of Contractual Buyout (hereafter, $\mathrm{CoBO}$ ) is a new "collectiveownership-administrative" strategy, which is designed to protect, and clinic sick units as well as gain the corporate control in the form of a takeover (if desired), and then achieve postmerger integration difficulties. We develop this model under the principles of leveraged buyouts (hereafter, LBO), and collective ownership and control. However, our model is similar to the market for corporate control activities, such as, mergers and acquisitions (hereafter, M\&A), takeovers, buyouts, and so forth (e.g., Jensen and Ruback, 1983). ${ }^{1}$ In the circumstances of low economic growth, buyouts would be effective tool while undertaking necessary policy reforms to focus on core business operations (Wright, Kitamura, and Hoskisson, 2003).

We frame the study by drawing on studies, such as, choice among mergers, acquisitions, alliances, collaborations, greenfield investments, joint ventures, and divestitures (e.g., Anand and Delios, 2002; Ariño and Ring, 2010; Elango and Pattnaik, 2011; Fjeldstad, Snow, Miles, and Lettl, 2012; Hennart and Reddy, 1997; Meyer, Estrin, Bhaumik, and Peng, 2009; Moschieri, 2011; Reddy, 2015b, 2015c; Slangen, 2011; Villalonga and Mcgahan, 2005; Wright, Kroll, Lado, and Ness, 2002). We also review the studies on restructuring, diversification, and performance (e.g., Bruton, Ahlstrom, and Wan, 2003; Chakrabarti, Singh, and Mahmood, 2007; Makhija, 2004; Matusik and Fitza, 2012; Miller, 2006; Oh and

\footnotetext{
${ }^{1}$ The authors review the extent studies on market for corporate control, and document that takeovers generate positive margins, which bidding firm shareholders do not lose where as target firm shareholders are benefited. Also, see Haleblian, Devers, McNamara, Carpenter, and Davison (2009) for the extensive review on extant merger literature.
} 
Contractor, 2012), and opportunities in corporate entrepreneurship (e.g., Madhok and Keyhani, 2012; Ragozzino and Reuer, 2010; Simsek and Heavey, 2011). We further select the studies on emerging multinationals, and their strategies reported by academic researchers in the recent years (e.g., Brannen and Voisey, 2012; de la Torre and Chacar, 2012; Govindarajan and Ramamurti, 2011; Peng, 2012; Ramamurti, 2012; Reddy, 2015a, 2015d; Westney, 2011). The above studies are being helped in research setting, theory building, and framework designing of this paper.

The 1980's initial buyout waves in the U.S.A. and UK have engulfed emerging economies to create a common platform for inorganic growth, especially M\&As and buyout fields. Contextually, LBO is a debt-collateral-acquisition transaction between an acquirer, and target firm. The prime motive behind LBO deal is to transfer stakeholders' wealth and tax gains; others include incentive realignment, and utilization of private information. During 1985-2005 in the UK, there were 12,267 buyouts of which 1,431(12\%) noticed protection from creditors (CMBOR, 2006 in [Cumming, Siegel, and Wright, 2007]). ${ }^{2}$ In the USA between 2004 and 2007, US \$535billion worth of LBOs completed, which was more than 10 times of the US \$50billion over the previous 8 years during 1996-2003 (Shivdasani and Wang, 2011). Whereas during 2007 financial crisis, both volume, and value of cross-border deals has plummeted in the western and developing nations, and then continued until 2009-10 (see UNCTAD, 2009, 2010). Economically and politically, largest LBOs are likely to have more impact on the economy (Opler, 1992). Earlier research describes various buyout models, and notices that momentous growth in operating competence and profitability during post-buyout period. However, either the engulfed LBO models, and guidelines does not suit the need, and requirement of industrial houses in emerging, and third world nations or they have become overloaded.

\footnotetext{
${ }^{2}$ The buyout market has all the time been striking by modernism in financial products, and financing arrangements. Hence, this trend seems to be different from vertical strip financing (Cumming et al., 2007).
} 
CoBO is a twofold-secured debt obligation, joint administration, and opportunity to buy target unit in the given period between acquirer, target firm, and financier in the market for corporate control. In particular, $\mathrm{CoBO}$ would be efficient inorganic magnetic for international venture capitalists, and private equity firms as a part of foreign market entry strategy. Specifically, it regulates unhealthy competition through monitoring monopoly activities. More specifically, it is a kind of contractual relationship (Dating-before-Merging), choice of market entry and expansion, and possibility to obtain tax advantage. Largely, it secures, and sustains more number of sick units to promise sustainable life for the citizens of country. More importantly, CoBO shall be the best-fit model for cross-border M\&A integration strategy. We explore policy implications, and develop CoBO propositions with reference to rigorous earlier contributions in the $\mathrm{M} \& \mathrm{~A}$ and buyouts field. CoBO propositions are useful in various implications, such as information symmetry and administrative changes, employment and employee role, operating performance and financial arrangement, tax savings, choice of market entry strategy, integration strategy and government and policy makers. Besides, firms can use $\mathrm{CoBO}$ as a takeover defensive strategy. To ensure state ownership on government enterprises, and protect sick companies in this global competition era, we introduce a model that would sustain the economic life of sick industries, and condense the monopoly power. Further, $\mathrm{CoBO}$ framework has illustrated through the virtual case, and recommending the government to enact new regulation in light of competition and trade. In case of non-enactment, we suggest the state for setting-up a committee to ensure better economic health, and uphold the ownership and control on government undertakings.

This article thus responds to the call issued by Lambrecht and Myers (2007), shows directions to develop an original model for benefiting the declining industries in emerging economies group. We aim to fill the void by answering an abstract query that does it possible to facilitate contract-clinic to sick industries in the M\&A and disinvestment perspective. 
However, the theory of takeovers and disinvestment suggested by Lambrecht and Myers (2007) mainly suits the advanced economies rather third world nations. Therefore, $C o B O-a$ policy framework has developed on the foundations laid via the existence of partial mergers in Japan (e.g., Akhigbe, Madura, and Spencer, 2004), LBO transactions in the Russian Federation (Kasparova, 2007), motivations for leveraged buyouts (Opler and Titman, 1991), role of buyouts in restructuring Central and Eastern Europe (Wright, Filatotchev, and Buck, 1993), consequences of LBOs (Bull, 1989; Fox and Marcus, 1992; Krause, 1989), buyout decisions in the UK (Weir, Lating, and Wright, 2005), and board structure and value creation in buyouts (Barun and Latham, 2007, 2009). Exclusive studies include hostage theory of joint ventures and partial acquisitions (Chen and Hennart, 2004), and employment effects and smaller LBOs (Amess and Wright, 2012). We then state our contribution to the study.

\section{Motivation and contribution of the study}

The conceptual foundation of this paper builds on four notions. First, the growing importance of emerging economies and their contribution to the universal trade, and commerce suggest that changing models of the global business situation motivate emerging country multinationals for improving network coordination and performance (e.g., de la Torre and Chacar, 2012; Peng, 2012; Ramamurti, 2012; Westney, 2011). Second, academic contributions on various key issues such as restructuring economies, synergies of alliances, partnerships, M\&A, and buyouts in diverse institutional environments notice that acquisition, alliance, collaboration, or buyout alternatives improve corporate growth especially in larger firms (e.g., Elango and Pattnaik, 2011; Fjeldstad et al., 2012; Slangen, 2011; Wang and Zajac, 2007; Wiersema and Liebeskind, 1995). Third, studies on foreign market entry strategies in various societal settings describe that acquisitions, greenfiled investments, and buyouts are important entry modes in emerging nations (e.g., Chen and Hennart, 2004; Harzing, 2002; Hennart and Reddy, 1997; Meyer et al., 2009; Reddy et al., 2014a, 2014b; 
Wright et al., 2002). Fourth, increased of awareness, and budding research on corporate entrepreneurship in the last decade report that buyouts create opportunities thus improves financial performance via entrepreneurship mode (e.g., Ragozzino and Reuer, 2010; Zahra, 1991). In sum, these outcomes have been motivated in theoretical building, and framework setting to our study. In addition to this, Fox and Marcus (1992) suggest that the current research in buyouts dreadfully deficient in multiplicity of conducts, henceforth more research require that passably judge the consequences of any new type of transaction. More specifically, Fox and Marcus (1992) research work has inspired us to develop new inorganicstrategy array that would improve the economic life of declining industries whilst adding new buyout model of CoBO to the existing theories, and hypotheses. In particular, Ramamurti (2012: 42) recommends that how the home-country setting motivates emerging multinational enterprises for corporate ownership and control advantage would be possible theme of advanced research. In other words, both demand and supply side issues may likely establish the concert of multinationals (Drummond, 2012). Therefore, the corporations for sustainable business may require new methods, and approaches (e.g., Khandwalla, 2002). Consequently, we have considered their recommendations while designing $\mathrm{CoBO}$ model.

Our article makes three contributions to the literature on acquisitions and buyouts, corporate entrepreneurship, and international business. ${ }^{3}$ First, CoBO framework is other side of the mergers and buyouts theories, which would append a couple of propositions for ensuring future research from budding strategy scholars in this field. Second, CoBO policy implications eventually motivate venture capitalists, and private equity players that they would preferably purse corporate entrepreneurship in new institutional dimensions. At the end, the suggested few insights in CoBO theory may inspire global corporate giants while choosing foreign market entry strategies, and it would be greater mix of hypotheses to the

\footnotetext{
${ }^{3}$ For information purpose, and cause benefitting the strategy researchers, we have discussed strategic aspects, but not financial aspects of the proposed CoBO framework. However, we have recommended few existing contributions in the subsequent sections of this paper that would help both economics and finance scholars.
} 
existing international business literature. An additional contribution of our paper is to document policy issues, and regulatory provisions of CoBO framework in light of legal and institutional context, and to the literature on market for corporate control.

The remaining article unfolds as follows. We begin the paper by selectively reviewing the existing research related to inorganic choices varying from alliances to LBOs. Thereafter, we describe the research setting, and theory building. We then present the proposed CoBO framework, followed by propositions, and conclude with a set of guidelines for future research.

\section{REVIEW OF EXISTING STUDIES}

Strategy, Law, Finance, and Economics research fields have been examined the diverse challenges associated with alliances, acquisitions, collaborations, divestitures, mergers, takeovers and so forth, usually ranging from negotiations to post-strategy actions. Notably, M\&A literature has grown by the orders of magnitude since Joel Segall published in 1968 (cf. Lambrecht and Myers, 2007). Lambrecht and Myers describe M\&A in two broad classes. First, exploit synergies and growth opportunities; second, seek greater efficiency through layoffs, consolidation, and disinvestment. We therefore present CoBO policy framework from the second class of M\&A field. Most studies found that M\&A seen as a means to maximize market share, geographical expansion, realize economies of scale, and so forth (e.g., Valentini, 2012). ${ }^{4}$

In a recent study, Pe'er and Gottschalg (2011) define that LBO is standalone, acquiring substantial shares of a company (or, a division) from its owners, typically with a limited time horizon, financed through a mix of equity and debt, and with robust participation from specialized banking institutions. In other words, when the acquisition financed largely

\footnotetext{
${ }^{4}$ Valentini (2012) explores the effect of merger on the patenting quantity, and quality of the firms involved in a deal; thus M\&A appears to be followed by significant decline in patents' impact, originality, and generality.
} 
by borrowing of all the stock, or assets of a hitherto public company by a small group of investors is also termed as LBO. In specific circumstances, LBOs occur when a firm is 'taken private' - the company's equity bought up and then delisted from publicly traded security markets (Fox and Marcus 1992). A firm with low debt-equity ratio would be well match for LBO deal, enchanting on substantial amount of debt (Loh, 1992).

In the earlier versions, LBO was a practice by which the owner/founder seeking to cash-out his investment transferred the firm to manage or younger family members, who can put up a small amount of capital, and borrow the rest (Kosedag, Mehran, and Qian, 2009). There are relevant studies on LBOs include cost savings, exchange listing, and tax savings (Bull, 1989; Landsman, Shackelford, and Yetman, 2002), agency costs (Shivdasani and Wang, 2011), free cash flows (Fox and Marcus, 1992), and informational advantages of managers (Opler and Titman, 1991). Moreover, LBO is most efficient in enhancing the oversight of the public firm without effective administrative control on firm operations (Bowman, Singh, Useem, and Bhadury, 1999). Most explanations for LBOs are based on trade-off theories of capital structure, and they create value via interest tax shields, lower agency costs, and operational improvements (Shivdasani and Wang, 2011). Further, Opler and Titman (1991) describe motivations for LBOs include incentive realignment, exploitation of inside information, stakeholder wealth transfer, and tax gains. In particular, Fox and Marcus (1992) document the causes and consequences of LBOs from two perspectives economic perspective, and behavioral perspective.

Historically, the concept of LBO was born in the nations of developed markets 'United States'. 5 Thus, buyouts have major implications to the market for corporate control

\footnotetext{
${ }^{5}$ Historically, LBOs, and leveraged cash-outs (LCOs) are the next wave to the end of conglomerated mergers in 1980s. Mergers have been proving significant increases in financial leverage by controlling the firm size and industry effects (e.g., Shrieves and Pashley, 1984; Weston, Chung, and Hoag, 1998). During the 1980s merger wave, corporate sector of the American economy was left with an enormous increase in debt/equity ratio (Jensen, 1984). On the other hand, LBO has become an increasingly frequent form of business streamlining. For
} 
(Fahrholz and Loslein, 1991), and the concept has wide applicability for streamlining the enterprises. If buyout market is to widen, three main elements to be present, generation of buyout opportunities, infrastructure to complete business deal, and investors prospect to sensible their margins (Wright, Thompson, and Robbie, 1992). In western economies, earlier work has acknowledged three types of buyout: efficiency buyouts, revitalization buyouts, and entrepreneurial buyouts (Wright, Hoskisson, Busenitz, and Dial, 2000). Therefore, our model is part of the revitalization. The 1980s buyout waves followed by a peak in default rates of highly levered companies, and the pace of LBO activity reached new record levels. Further, it represent 5,000 worldwide deals completed during 2005-07 for US\$ 1.6 billion have been occupied 30 per cent of deals, and 43 per cent of trade share to the cumulative historic since 1980 (cf. Kaplan and Strömberg, 2009). Evidently, LBO transactions support the notion that leveraged dealings produce synergistic value (Guo, Hotchkiss, and Song, 2011).

Wright et al. (1993) analyze issues involved in the application of buyout concept and the role of reengineering Central and Eastern Europe's economy. In the UK, buyouts normally occur in four kinds: complete enterprise buyouts, multiple buyouts on the breakup of a state form, buyouts on disinvestment of non-core activities, and buyouts of previously non-commercial governmental or quasi-governmental activities (Wright and Buck, 1992). Wright, Thompson, Robbie, and Starkey (1994) describe that the majority of buyouts in the West do keep their original structures for five years or more, observe significant minority changes after a buyout. In particular, public to private LBOs have been taking place in considerable volumes in Europe, Japan and other Asian economies (Siegel, Wright, and Filatotchev, 2011).

In order to achieve the goal of study, we present empirical results of previous studies on LBOs operating performance. Previous studies strongly report that buyouts enhance occurred in 1989 (Loh, 1992). 
financial performance (e.g., Kaplan, 1989). The evidence shows that after LBOs, there have been significant improvement in operating efficiency and profitability, and no decline in the expenditure for such attributes, i.e. maintenance, and advertising (Fox and Marcus, 1992). Peter F. Drucker states that the merged companies' evaluation record is inadequate particularly conglomerate, with which they had little in common - an emblematic financial conglomerate. Only three out of ten acquirers do as well two years later as they did prior to the merger. Nevertheless, the evidence of companies that have been acquired in a hostile takeover is consistently dismal (Drucker, 1986 in [Bull, 1989]). Opler (1992) investigates the consequences of LBOs on operating performance of 44 going-private transactions completed during 1985-89 in the UK. His findings were not escorted by smaller operating improvements than observed in earlier transactions.

Bull (1989) compares the management performance before and after LBOs; financial performance after the buyouts is superior compare to before the buyouts. The enhancement is superior to income tax savings alone. Similarly, impact of LBOs on 64 larger U.S. firms examined by Wiersema and Liebeskind (1995), supports that large LBOs tumbling divisions of business, diversification and expansion, and provides discipline, which leads to job waning to the larger extent. Some of the eminent scholars suspect that LBOs create substantial storm among academicians, industrials, and public policy makers (cf. Zahra, 1995). Zahra examine 47 LBO deals, exhibit augmentation in the product enrichment, technology related alliances, R\&D employee size and skills, and new business creation activities during post-LBO period.

Contrary to the larger buyouts, smaller companies' LBOs do not seem to depend greatly on disposing assets, or laying-off employees, instead, foremost changes in the smaller LBOs lie in the area of increased marketing, and revenue augmentation (Malone, 1989). Malone analyzes 56 LBOs during 1981-87, shows that small LBOs relatively protect from foreign competition. Specifically, Loh (1992) describes LBO firms have higher average 
levels of debt, and operating efficiency before the buyout than do other firms. Roden and Lewellen (1995) consider a large sample of LBO transactions in the United States during 1981-90. They found that financing package is intended scientifically respond to differences across firms, these are growth prospects, variability of their earnings, liquidity characteristics, and opportunity to achieve tax savings. Similarly, Krause (1989) describes that LBOs achieve remarkable success in return on investment, and value creation despite their borrowing costs are very high. In a recent study, Guo et al. (2011) examine 192 LBOs during 1990-2006, which are more unadventurously priced, and less levered than observations documented in the 1980s. Guo et al. report that, on average, the firms experience large increases in total value from the time of the buyout to their subsequent exit from a private equity firm's portfolio, producing large returns to invested debt, and equity holders. More specifically, Pe'er and Gottschalg (2011) study the affect of the institutional context on buyout investments, propose that the formal, and informal institutional environment in 'red' states is more associated with the strategies through which investors create value than such a context is in 'blue' states. ${ }^{6}$ Amess and Wright (2012) analyze 533 LBO deals occurred during 19932004, conduct systematic analysis enumerate the effect of private equity, and LBO supremacy on employment, find no job effects reliant on the size of the target firm.

We then purposively present few studies on the restructuring, and turnaround effect in different institutional contexts. In the view of sick company's turnaround effect, Khandwalla (2002) suggest seven sets of activities to develop four typologies of turnaround strategy based on retrenchment of people and technology up-gradation. ${ }^{7}$ Bruton et al. (2003) investigate the

\footnotetext{
${ }^{6}$ Pe'er and Gottschalg (2011) examine 10,746 U.S. buyout investments in 4,633 distinct target companies made by 2,396 different funds managed by 1,300 private equity firms during 1980-2003. The institutional setup in blue states (dominated by the Democratic Party) would create higher transaction costs related to the implementation of restructuring-oriented buyout value-generating strategies than the institutional setup in red states (dominated by the U.S. Republican Party).

${ }^{7}$ Most of the studies in turnaround administration conclude that all typology efforts explored from work force reduction to orbit firms (cf. Robbins and Pearce, 1992). They classify turnaround strategy into an efficiency driven, and competition driven.
} 
turnaround strategies of overseas Chinese firms in East Asia, the importance of relationships among business people constrain the applicability of prior U.S. research to East Asia. In a similar study, Makhija (2004) study 988 restructuring firms in Czech Republic found that restructuring significantly reduced the value of firms. ${ }^{8}$

We now focus on the related literature that covers diversification, and divestitures in various institutional contexts. Miller (2006) states that conglomerate firms produce more value from technological diversity than do single segment firms, and perform superior as technological diversity increases. Chakrabarti et al. (2007) find that institutional environments, economic stability, and business group affiliation influence the outcomes of diversification. ${ }^{9}$ In a recent study, Matusik and Fitza (2012) examine diversification in the context of venture capital firms. Firms benefit from either low or high levels of diversification; moderate levels generate the weak results. However, contacts and connections are more important than competencies and technological abilities for determining the incentives and outcomes of diversification in such environments (Kock and Guillen, 2001). In a course of divestiture program, Moschieri (2011) describes that past-history alone would be inadequate for understanding the outcomes of divestitures; thus may also affect perceptions of divestiture feasibility. ${ }^{10}$ Similarly, Chakrabarti, Vidal, and Mitchell (2011) examine reconfiguration activity of 1,256 firms based in eight South-East Asian economies; argue that more developed infrastructure facilitates resource reconfiguration, assisting weak firms' attempts to retrench and strong firms' attempts to grow. The above all helped us in research setting and theory building, which will be presented in the next section.

\footnotetext{
${ }^{8}$ In few institutional environments, for example, a spin-off occurs when a firm distributes controlling stock in a subsidiary to the current equity investors of the parent firm, whereas a 'carve-out' refers to a division of a firm, which is sold to new equity investors, or to a different firm.

${ }^{9}$ Chakrabarti et al. (2007) study the impact of diversification on performance for 3,117 firms in six Asian countries (Indonesia, Japan, Malaysia, Singapore, South Korea, and Thailand) during 1988-2003. Results evidence that diversification negatively influences the outcome in more developed institutional environments while improving performance only in the least developed environments.

${ }^{10}$ Divested units are more likely to perform better if the divesting process is cleverly managed; however, it depends on the involvement of unit managers, and on the creation of an independent firm with a new identity and strategy (Moschieri, 2011).
} 


\section{RESEARCH SETTING (THEORY BUILDING) - A PRAGMATIC APPROACH}

We review the exhaustive literature contributed by western authors in specific and recent studies in general on various key issues of inorganic choices such as joint ventures, alliances, networks, mergers, acquisitions, takeovers, LBOs, management buyouts, partnerships, and so forth (e.g., Ariño and Ring, 2010; Capron and Guillén, 2009; Elango and Pattnaik, 2011; Fjeldstad et al., 2012; Pe'er and Gottschalg, 2011; Slangen, 2011; Villalonga and Mcgahan, 2005). We further comprehend the previous studies on definite strategies such as diversification, turnaround, and foreign market entry modes (e.g., Bruton et al., 2003; Chakrabarti et al., 2007; Hennart and Reddy, 1997; Matusik and Fitza, 2012; Oh and Contractor, 2012; Reddy, 2015b, 2015c). More specifically, we recognize various linked perceptions on buyouts and entrepreneurship (e.g., Ragozzino and Reuer, 2010), emerging economies and inorganic-tactics (e.g., Brannen and Voisey, 2012; Ramamurti, 2012), and other allied contributions in the mergers and buyouts research. Thereafter, we have described reviews systematically and then, borrowed their concrete guidelines for building a strong foundation to a theory proposed in the following section of this paper. In fact, hypotheses formulated, rigorous methodology employed, and findings discovered by prominent authors in western world (e.g., U.S., and UK outcomes) assisted us to narrow-down the framework developed in specific perceptions, propositions, and limitations.

Consistent with the future research agenda suggested by Wright, Chiplin, Thompson, and Robbie (1990), Zahra (1993), Chaganti and Schneer (1994), Phan, Wright, Ucbasaran, and Tan (2009), Ramamurti (2012), and Siegel et al. (2011), we incorporate their recommendations in the suggested CoBO theory for continuity and development in the existing literature. Eventually, CoBO model would flourish M\&A and buyout literature to benefiting both the third-world countries, and emerging nations. In the next section, we present foundations and characteristics of the proposed framework. 


\section{CONTRACTUAL BUYOUT (CoBO)}

\section{Foundation setting}

The valuable contributions made by Bowman et al. (1999), Bull (1989), Fox and Marcus (1992), Guo et al. (2011), Jensen and Ruback (1983), Loh (1992), Opler (1992), Reddy (2015a, 2015d), Roden and Lewellen (1995), Shivdasani and Wang (2011), Wright and Buck (1992), Wright et al. (1994), Wright et al. (2000), and Wright et al. (2003) helped as deep-seated pedestal to supply this well-structured theoretical framework for protecting the government, and sick companies on the initiative stones laid in the U.S., for example, RJR leveraged buyout by KKR \& Co (e.g., Dalton, 1989; Landsman et al., 2002), smaller company LBOs (Malone, 1989), role of buyouts in restructuring Central and Eastern Europe (Wright et al., 1993), partial mergers in Japan (Park and Russo, 1996; Ushijima, 2010), partial acquisitions by Japanese firms in the U.S. (Chen and Hennart, 2004), LBO transactions in the Russian Federation (Kasparova, 2007), and industrial diversification and partial privatization (Lin and $\mathrm{Su}, 2008$ ). Recently, Amess and Wright (2012) analyze the employment effects of PE-backed and non-PE-backed LBOs. As part of the foundation to the model, financing $\mathrm{CoBO}$ transaction is a larger task, however, we recommend few studies to solve this issue for benefiting the finance and economics scholars. ${ }^{11}$ More specifically, we consider recent studies on various issues examined in emerging economies (e.g., de la Torre and Chacar, 2012; Meyer et al., 2009; Peng, 2012; Ramamurti, 2012), choice among growth strategies (e.g., Balakrishnan and Koza, 1993; Kock and Guillen, 2001; Lockett, Wiklund,

\footnotetext{
${ }^{11}$ The studies purposively suggested here are ranging from contracting to financing buyouts. Generally, buyouts funded by the investment bankers as a debt. Conventionally, more than 90 per cent of LBO deals purchase price of an acquisition financed by debt, and the tangible assets of target firm that have been used as collateral for loan amount (Kasparova, 2007; Ray, 2010). Finance researchers may refer for the extensive review on financing LBOs in Russian Federation (Kasparova, 2007), other contributions include Axelson, Strömberg, and Weisbach, 2009; Braun and Latham, 2007; Chaganti and Schneer, 1994; Chen and Hennart, 2004; Cumming et al., 2007; Fishman, 1989; Phan et al., 2009; Prasch , 1992; Schlingemann, 2004; Siegel et al., 2011; Wier et al., 2005; Wright, Robbie, and Thompson, 1989; Wright et al., 2003. Selectively, we recommend the recent studies on methods of payments in asset sales (Slovin, Sushka, and Polonchek, 2005), and the role of collateralized debt obligations in LBOs boom (Shivdasani and Wang, 2011). Scholars may also study the well-examined paper on reverse leveraged buyouts (Braun and Latham, 2009).
} 
Davidsson, and Girma, 2011; Slangen, 2011), and corporate entrepreneurship (e.g., Madhok and Keyhani, 2012; Ragozzino and Reuer, 2010).

The Theory of the Growth of the Firm by Edith Penrose, first published in 1959, is a seminal contribution to the field of management (Penrose, 1959). This theory postulates that a firm's current growth rate would be inclined by the adjustment costs of, and changes to a firm's productive opportunity set arising from, previous growth. Penrose made it understandable that organic growth and acquisitive growth are two different strategic choices (cf. Lockett et al., 2011). For example, when two firms communicate to transfer rights for operating a business, the option between an acquisition and an alliance for one of the firms amounts to a choice between a divestiture and an alliance (Villalonga and Mcgahan, 2005: 1183). ${ }^{12}$ In fact, a larger firm can acquire the assets of the smaller unit; or the larger firm can sell its assets through a divestiture to the smaller unit. It all happens because of one fundamental reason that two firm's combine their resources to enhance superior value by experiencing possible synergy between them (Wang and Zajac, 2007: 1294).

Lockett et al. (2011) extend Penrose's work for examining the impact of organic and acquisitive growth on current organic growth of Swedish firms; results state that previous acquisitive growth has a positive effect on current organic growth. More importantly, Balakrishnan and Koza (1993) describe joint venture as a tool for diminishing the transaction expenses deserved when acquiring other firms. Similarly, Hennart and Reddy (1997) investigate the determinants of the choice between merger /acquisition and the greenfield equity joint venture on 175 Japanese investments in the U.S. during 1978-89. Results show that equity joint ventures are preferred over acquisitions when the desired assets connected to

\footnotetext{
${ }^{12}$ Villalonga and Mcgahan (2005) investigate how firms choose among acquisitions, alliances, and divestitures on 9,276 deals completed by 86 members of the Fortune 100 between 1990 and 2000. Based on resources, they state that transaction costs, internalization, organizational learning, social embeddedness, asymmetric information, and real options theories are highly related, and complementary.
} 
non-desired assets. ${ }^{13}$ In collaboration settings, efficiency and effectiveness in the interaction among actors increase by way of actor capabilities and values, commons, protocols, processes, and infrastructures (Fjeldstad et al., 2012). ${ }^{14}$ In fact, partner specific knowledge between a pair of firms influence the likelihood of firms forming an alliance vs. acquisition (Wang and Zajac, 2007). ${ }^{15}$ On the other hand, with the higher levels of ownership incentives senior executives often motivated to acquire risk-enhancing enterprises (Wright et al., 2002). A query raised by Chen and Hennart (2004), state that partial acquisitions create a hostage effect that compose likely ex ante selection of targets and ex post enforcement of deals ${ }^{16}$ Conceptually, A partial acquisition represents a unique form of corporate restructuring because it alters the ownership structure of two entities (in opposite ways). These acquisitions represent a shift in control, and allow unique opportunity to measure how the effects on performance levels of the partial targets are conditioned (Akhigbe et al., 2004). ${ }^{17}$ Partial merging firms usually large, and more diversified whilst partner firms tend to have more heterogeneous industry backgrounds (Ushijima, 2010). For example, partial acquisitions yield positive, and considerable abnormal returns to large and small firm shareholders in the Japanese institutional setup especially manufacturing sector (Park and Russo, 1996).

In the last few decades, the choice of entry strategy into global markets has received a lot of interest from both the developed and emerging business researchers. Many studies have surveyed factors that influence the option for different entry modes, often examined diverse alternatives such as licensing, joint ventures, and wholly owned subsidiaries (cf. Harzing, 2002). Anand and Delios (2002) analyze choices of global entry on 2,175 entries by UK,

\footnotetext{
${ }^{13}$ The results also show that the greater the Japanese's investor experience of the U.S. market the more likely they will choose acquisitions over joint venture (p. 11).

${ }^{14}$ However, multiparty collaboration is critical to the effective solution of complex problems and continuous adaptation to changing environments.

${ }^{15}$ Combined alliance capabilities increase an alliance formation, and an acquisition between two firms.

${ }^{16}$ Acquisition is partial, if Japanese parent buy less than 80 per cent of equity stake in the US target firms (Chen and Hennart, 2004: 1133).

${ }^{17}$ Akhigbe et al. (2004) examine 330 partial acquisitions from 1980 to 1998. The long-term performance effects are more favorable when the partial target has more growth opportunities, a lower degree of financial leverage, and when the partial acquirer is related and closer in size to the partial target.
} 
German, and Japanese investors in the U.S. during 1974-91. In case of downstream capabilities, which tend not to be geographically fungible, the absolute level of capabilities in the entered industry explains the mode of choice; however, it shown contrast results for upstream capabilities. In a weaker institutional framework, joint ventures used to access many resources, but in a stronger institutional framework, joint ventures become less significant while acquisitions can play a key role in accessing resources that are intangible, and organizationally embedded (Meyer et al., 2009). ${ }^{18}$ Specifically, Ariño and Ring (2010) demonstrates that fairness considerations would play an essential task in international joint ventures. ${ }^{19}$ Allatta and Singh (2011) examine changes in worker communication networks between the acquiring and target firms' employees during post-acquisition integration, found that target firm workers' positions within their contacts are sluggish to change.

The increased market integration may lead firms to ascertain closer managerial coordination among subsidiaries to an extent proportional to the strength of external changes (cf. de la Torre and Chacar, 2012). For example, designing a governance contract to align interests of managers, and shareholders rather than simply developing governance structures that reduce the costs of effecting a transaction would seem to be important (Filatotchev and Wright, 2011). More interestingly, emerging economies have opened their markets, resulting in increasing competition from foreign firms. To cope with the influx of new competition, emerging country multinational enterprises (EMNEs) employ serial acquisitions to build capabilities (Elango and Pattnaik, 2011). ${ }^{20}$ In a related study, Slangen (2011) examine 231 entries by Dutch MNEs into 48 countries during 1996-2003, evidence that geographic and

\footnotetext{
${ }^{18}$ Analyze the entry strategies of foreign investors entering emerging economies include India, Vietnam, South Africa, and Egypt for knowing the impact of market-supporting institutions on business strategies.

${ }^{19}$ Fairness can be a key element to the success of such formation processes by shaping the logics partners apply in evaluating the efficiency of a potential alliance, and in making a final decision whether or not to form an alliance under negotiation, and other variants of fairness can be found at play.

${ }^{20}$ They examine 175 acquisitions made by Indian firms during 2000-2006, found that firms acquire targets serially but of increasing value in a sequential manner to learn, and build capabilities thus resulting in reducing risk as well as optimizing their ability to learn from the acquisitions.
} 
linguistic barriers to verbal communication play important roles in MNEs' establishment decisions. ${ }^{21}$ Therefore, developed country MNEs (DMNEs) have had gear up to exploit new opportunities and resources in emerging markets, and EMNEs have had to figure out how to take advantage of them in the rest of the world (Ramamurti, 2012).

Most prior research in the field of global strategy focuses on what choices executives make to build the competitive advantage of a firm, from setting up activities in different locations to coordinating the linkages between them (cf. Bouquet and Birkinshaw, 2011). Brannen and Voisey (2012), and Nachum (2012) seek understanding of the role of comparative learning in global strategy formulation. Nachum describe that comparative approach is particularly appealing in relation to international strategy, and comparisons are at the sympathy of business strategy. The international business environment by the increase in the number of organizations acting across borders has been affected by the actions of EMNEs, NGOs, and governments (Westney, 2011). In recent days, the global strategy of multinational enterprises from China also started to establish geographic advantage (Peng, 2012). ${ }^{22}$ Oh and Contractor (2012) illustrate that territorial scope covered by the firm makes a substantial difference to the relationship between multinationality, and performance. Therefore, global firms need to distinguish the crucial role of foreign subsidiary strategy in building global competitive advantage, and emphasizing corporate control (Pehrsson, 2012). Pehrsson found that greater business relatedness and business scope of the subsidiary weaken the negative impact of competition barriers on subsidiary performance. For example, privatization law in Poland allows for a procedure of liquidation, buyout occurs when incumbent management and employees create a private enterprise to lease state assets.

\footnotetext{
${ }^{21}$ Slangen develops a communication-based theory of the choice by MNEs between greenfield and acquisition entry; argues that MNE parents communicate with their subsidiaries for reasons of knowledge exchange, coordination, monitoring, and socialization.

${ }^{22}$ They propose three relatively unique aspects: (1) the previously underappreciated role played by the home country governments of MNEs as an institutional force, (2) the challenge of going abroad in the absence of significantly superior technological and managerial resources, and (3) the rapid adoption of acquisitions as a primary mode of entry.
} 
Similar models observed in Russia, and other emerging economies like Mexico, Hungary, Romania, Slovenia and other nations in CEE region (Wright et al., 1993). Specifically in China, buyouts reflect conflicts among the government's desire to retain political control, whereas private investor's desire for return on their investments (Su, 2005). Cain, Denis, and Denis (2011) examine 990 acquisitions during 1994-2003, document specific contractual terms of acquisition agreements contain earnouts. ${ }^{23}$ Consistent with this background, we introduce $\mathrm{CoBO}$ theoretical framework, which includes definition, parties represent in the model, guidelines, and merits.

\section{What is CoBO?}

CoBO is an extension, and shall be next wave to the LBOs, which would be a part of the inorganic growth strategy. Further, it appears similar to a Futures Contract in the derivatives market. The buyout agreement shall be happen before the true mix of balance sheets of both the companies, i.e. acquirer and target firm. When the agreement takes place, the acquirer firm will create a subsidiary unit for joint management whilst operations controlling by the target firm corporate board. It means that the acquirer share their expertise, technology, work force, and operational activities with target firm for strengthening financial position, employee sustainability, and corporate responsibility in the industry. In addition to this, it protect the public interest through virtual acquisition of the target firm by investing nominal, or required amount with the financial courtesy of an investment banker, or financier in the form of debt. Specifically, the acquirer firm provides an acknowledgement of guarantee to the amount of debt funded by the lender.

We define the proposed $\mathrm{CoBO}$ as follows. Three or more parties agree to form a combined entity, or live like a single entity after the immediate collapse of CoBO deed/agreement when settling the agreed financial arrangements among the involved parties,

\footnotetext{
${ }^{23}$ Earnouts represent payments to shareholders in M\&A deals and contain two components: an upfront fixed payment and additional future payments that are contingent upon some apparent appraisal of performance. These later payments are called earnouts (p. 152).
} 
which usually occur in the premises of court, is called a contractual buyout. Mandatory parties include Acquirer, Target firm, and Financier/Lender ${ }^{24}$ Briefly, it is a takeover defensive tactic, choice of foreign market entry option, and opportune to get tax advantage. From the government perspective, it ensures monitoring, and administering the public sector units to protect public and society interest whilst controlling the monopoly character in the business. Largely, it secures, and sustains more number of sick units to promising sustainable life for the citizens of a country. CoBO would be efficient inorganic magnetic for VCs and PEs as a part of foreign market entry strategy. More specifically, CoBO would be the best-fit model for cross-border M\&A integration strategy.

\section{Elements of the agreement}

1) $\mathrm{CoBO}$ should have three parties - acquirer, target firm and financier.

2) Acquirer business value shall be equal, or more than five times of the target firm business value (not necessarily in all situations), hence, financier recommendation plays a key role.

3) It is not necessary that the parties should be in the same business line. It can be conglomerate, or diversified. Reasons for merging the target firm balance sheet with acquirer balance sheet should be on the following primary/border line of the proposed CoBO model. The reasons include disinvestment, turnaround strategy of sick industries, corporate restructuring, expansion strategy, entry of new markets, diversification as a choice, and party's interest in the context of law.

4) Parties should satisfy leverage norms, guidelines, and requirements while permitting debt service by the select investment banker

5) The following conditions should be satisfied while CoBO deed turns-on

i) No party should void the contract

\footnotetext{
${ }^{24}$ The financier or lender can be venture capitalist, private equity, or investment banker.
} 
ii) Contract period can be three, or five years

iii) If an acquirer wants to break up, or not to continue the corporate life with target firm, primarily the acquirer has to repay the commission received earlier, and clears the remaining amount of debt.

iv) If target firm wants to break up their deed with the acquirer before completion date, simply it has to merge with acquirer, and then acquirer has to bear the remaining debt amount along with interest.

v) During the agreement time, acquirer may buy any other assets, business units, or equity stake in the market. Alternatively, it can sell their own-stake to some other party, but the other party should consider CoBO deed as a contingent liability.

vi) During the contract, target firm have no right to sell their equity, asset stake, or control to someone, or entering any agreement without board approval of the acquirer firm.

vii)Further, no company/person have right to buy the target company (even in open market) during the CoBO deed.

6) Acquirer gets a certain percent of commission on future sales of the target firm, which can be, from the half of the contract time (For example, from third year on-ward in a five years contract).

7) Whereas, target firm is essential to pay the interest amount from third year onwards until the completion of $\mathrm{CoBO}$ deed, or clearance of debt, whichever is earlier. From fifth year onwards, target firm has to pay both interest, and principal amount, if the deed has written for seven years. If any principal amount is left in the deed, that amount must be partially paid by an acquirer through its subsidiary company.

8) If target firm do not want to continue like a single entity after the collapsation of an agreement, it has to merge with acquirer (desire to continue), therefore, no option for 
the target firm. Further, two balance sheets merge after paying the debt obligations of the target firm by acquirer's subsidiary firm.

9) If target firm wants to continue like a single entity, first the CoBO deed must be windup along with financial arrangements, which was funded by the investment bankers.

10) Finally, obtaining No Objection Certificate from all the parties with seal in the premises of court, later target firm may continue like single entity. In the first year of deed completion, target firm has no right to merge, acquire, or takeover with, or by any other company.

\section{Contractual Buyout (CoBO) model:}

The proposed contractual buyout model has depicted in Fig. 1. This model explains the involvement of parties, actions that could be taking place between the parties, and then how the merger occurs from the CoBO model. Further, it explains various issues related to participation in the CoBO model.

\section{[Insert Figure 1 about here]}

The model, or theory portrayed in Fig. 2 describes three phases namely CoBO period, simple merger, and single entity, defining as main streams of contractual buyout. The following illustration explains CoBO framework, then how it could be executed whilst convincing the existing literature.

\section{Illustration:}

Fig. 2 shows CoBO model, and describes how it can turnaround a sick unit into economic-value based entity. Assume that two parties involved in CoBO model, acquirer and target firm. To enumerate, we have taken time line on $\mathrm{x}$-axis and growth line on $\mathrm{y}$-axis in the given pictorial diagram. Various studies describe that firm can grow on two streams, which

states organic growth line (OGL), and inorganic growth line (IOGL). Logically, a firm becomes cash-rich entity by choosing inorganic choices (e.g., joint ventures, mergers, 
amalgamations, acquisitions, buyouts), and elected fast whilst higher growth rate compare to the conventional organic growth strategies (e.g., new product development, new market).

Predict that a target firm profit had fallen at 6th year, point A and then continuing the losses, thus the reasons could be plummeted sales, low technology, hyperactive competition, and higher product cost in contrary to the availability of low cost product in the market. At 9th year and point $\mathrm{B}$, target firm has entered $\mathrm{CoBO}$ agreement with an identified acquirer for the period of five years. As a result, target firm would come out from the losses (recovery trend) by the end of 4 th year of contract period in 13 th year at point C. Further, it would have more chances to get into profits line. Hence, contract period shall complete at point D in the 14th year. After CoBO period collapses, target firm has right to continue its previous phase like single entity, or simply, it can merge with acquirer. Lastly, acquirer would be getting an opportunity to achieve socio, cultural, economic, and operational integration without technical errors. More importantly, post-merger integration can be administered without any complexity by choosing $\mathrm{CoBO}$ model for inorganic growth.

\section{[Insert Figure 2 about here]}

\section{PROPOSITIONS AND POLICY IMPLICATIONS}

In addition to the foundation of model, we conceptualize CoBO propositions on the basis of seminal work documented such as, internal operating changes (Malone, 1989; in buy-ins, Robbie, Wright, and Thompson, 1992), diminution of political costs (Bull, 1989), information irregularity (Howorth, Westhead, and Wright, 2004), employee participation (Chaplinsky, Niehaus, and Van de Gucht, 1998), improving marketing system and financial competence (Niederfolker, 1991; Shivdasani and Wang, 2011), capital for administration (Cumming, 2005), venture capitalists investment support (Wright and Lockett, 2003), crossborder PE financing (Mevleman and Wright, 2011), deductions in income tax (Bull, 1989), 
tax savings for LBOs (Fox and Marcus, 1992; Opler and Titman, 1991; Roden and Lewellen, 1995), new business through market progress (Zahra, 1993), equity in established firms (Parker and van Praag, 2012), global market entry choice through partial acquisitions (Chen and Hennart, 2004), government venture capital funds (Cumming, 2007), and raising the need of monitoring PE and LBO acquisition process (Siegel et al., 2011).

To the best of our knowledge, no academic validation has recognized a merger, or buyout framework that protects government, and loss making industries. In this regard, strong evidence that government controlled diversified firms has lower Tobin's $\mathrm{q}^{25}$ than nongovernmental controlled firms, whereas valuation effect depends upon government control (Lin and Su, 2008). Disinvestment used as a defense against takeovers (Lambrecht and Myers, 2007), further buyout concept can apply to acquire the falling firms. In addition to the above tactics, buyouts applicable to institutions where considerable amount of investment has been required (Wright et al., 1993). For example, buyouts providing a means for Japanese corporations to reorganize in order to face up confront of difficult economic conditions, and increasing competitive pressures (Wright et al., 2003). Their implications include management of large corporations, managers of subsidiaries, government policy, and foreign investors. We consider that $\mathrm{CoBO}$ framework would be well fit for the emerging market economies, and other third world nations at greater macroeconomic benefit. Further, we robustly support the work, and hypotheses developed in earlier research that suits our model, and accommodating those guidelines for policy implications as follows. Fig. 3 presents both the foundations, and propositions explored in this study.

\section{[Insert Figure 3 about here]}

\section{Information symmetry and administrative changes}

\footnotetext{
${ }^{25}$ Tobin's q is the ratio of market value to current replacement value of a firm's non-financial assets (Weston $e t$ al., 1998). Finance scholars may see for illustrative examples in Damodaran (2002).
} 
In the course of post-buyout internal operating changes, anticipate that the locus of verdict making would shift towards the pilot investor, and managerial compensation become incentive based (Malone, 1989). This would be possible impact factor on leadership, and middle level managers of acquirer firm. In the context of political and associated risks, we support the views of Bull (1989), while fragmenting CoBO deal domestically, or internationally as a market entry tactic. ${ }^{26}$ However, information asymmetries were common in nature, transparency while negotiating deal consideration, and deal framework, though the level of information irregularity influences it (Howorth et al., 2004: 510; Shivdasani and Wang, 2011). We explore propositions in light of compensation, and political costs.

Proposition (1): Acquirer managerial skill influences the target firm middle managers, and significant rise in compensation.

Proposition (2a): CoBO deal success, or failure do not influences by political risks, and rebuff to associate political costs.

Proposition (2b): Exchange of transparent information between acquirer, target firm and financier while negotiating $\mathrm{CoBO}$ deal.

Another study in buy-ins by Robbie et al. (1992) describe administrative changes materialize to be momentous, extensive changes in buyouts considerably greater compared to buy-ins. It reproduces an asymmetric information dilemma that is higher in buy-ins than buyouts. On the other hand, Thronhill and Amit (2000) identify two proportions of the fit between parent houses and their venture firms: relational and economic. A relational fit replicates organizational culture and structure, and economic fit is a function of the needs of the venture and the resources of the parent. Hence, success connects with awareness, commitment and association, and appears to have a greater relationship with venture success than does the economic dimension (Thronhill and Amit, 2000). In the context of management

\footnotetext{
${ }^{26}$ Political costs are expected to be reduced for one segment of LBOs, i.e. publicly held corporations that go private. However, they do not deserve out-of-pocket costs related to serving outstanding shareholders, meeting regulatory reporting requirements, and maintaining relationships with analysts (Bull, 1989: 265).
} 
buy-ins, ${ }^{27}$ Robbie et al. (1992) notice better monitoring in buy-ins compare to buyouts. However, CoBO imparts acquirer administrative supremacy on target-firm business activities further monitors market and industry adjustments in the business environment. The following proposition presents concerning the post-CoBO administrative changes.

Proposition (3): Optimistic administrative changes, and superior monitoring in the target-firm operations during $\mathrm{CoBO}$ deed, and post-CoBO period compare to prior the deal.

Interestingly, Zahra (1995) documents changes in entrepreneurial actions, evaluation and connection between entrepreneurial activities, and performance. His hypothesis, company's commitment to corporate entrepreneurship activities increases after LBO is an additional recommendation for $\mathrm{CoBO}$ model. We suggest acquirers, and financiers consider the above issue while designing post-contractual integration strategies. We introduce proposition in view of entrepreneurial activities.

Proposition (4): CoBO models improve entrepreneur's self-confidence, and capability of target firm entrepreneurial activities.

\section{Employment and employee role}

Employee participation plays an extreme role while restructuring labor contracts, resulting changes make easy financing of buyout, and the ownership structure that emerges in employee buyouts usually features a large degree of managerial control (Chaplinsky et al., 1998). In particular, Robbie, Wright, and Ennew (1993) examine 64 receivership buyouts during 1990-92, potentially viable divisions, or sub-divisions of failed groups has made buyout attempts prior to collapse, and that managers often had an alternative employment opportunities after buyout. Typically, buyouts tend to employ fewer jobs compare to other firms in the similar industry (Kaplan, 1989). The following proposition is configured regarding employment and employee role.

\footnotetext{
${ }^{27}$ Management buy-in (MBI) is buying a firm through external entrepreneurs, where as management buyout is the purchase of the firm by a group of normally four to six senior managers who are already employed in the business typically using their own funds plus external private equity, and bank loans (Howorth et al., 2004).
} 
Proposition (5a): CoBO arrangements do not affect on target firm employment, and then, there would be minor managerial changes at middle level.

Proposition (5b): Defining and recognition of target firm employee responsibility and his (her) role in decision-making leads to accumulate firm performance during CoBO deed.

\section{Operating performance and financial arrangement}

Corporate entrepreneurship (CE) is important for a company's survival, profitability, and growth (Zahra, Filatotchev, and Wright, 2009). More specifically, Simsek and Heavey (2011) indicate that CE is positively associated with knowledge-based capital, and through this, with performance. Niederfolker (1991: 239) describes that a mixture of small firms' expertise with larger firms marketing system, and financial competence promises margins. His core hypothesis also proposed to advocate CoBO policy. ${ }^{28}$ By contrast, Cumming and MacIntosh (2006: 570) suggest that $\operatorname{LSVCCs}^{29}$ are mediocre organizational forms, which reveal higher agency costs, and lesser returns. The generous tax subsidies underlying the LSVCC programs lower the required rate of return, allowing out-bid other types of funds, drive up deal prices, and lower returns in the market. This could have been occurred due to well-developed markets, and we strongly acclaim that lesser agency costs, and mediate returns can be observed in emerging nations, moreover our model incurs only initial costs when deed takes place (Shivdasani and Wang, 2011). Zahra (1995) observe amendments in different activities during post-LBO period, were optimistically associated with changes in firm performance. Further, we incorporate his hypothesis ${ }^{30}$ to validate the proposed model for industry effectiveness whilst augmenting the professionalism of CE. Cumming et al. (2007) notice that buyout performance has been consistent with superior risk adjusted performance

\footnotetext{
${ }^{28}$ Why did your company get involved in this relationship and has the cooperation been developing overtime?

${ }^{29}$ Canadian governmental subsidization of venture capital firm, Labour Sponsored Venture Capital Corporation (LSVCC).

${ }^{30} \mathrm{H} 2 \mathrm{a}$ : company's performance will be higher after an LBO than before the transaction, and

H3: Changes in post-LBO corporate entrepreneurship (venturing and innovation) are positively associated with company financial performance.
} 
relative to industry yardstick. We intend propositions on financial performance during negotiations, and post-CoBO period.

Proposition (6a): Target firm operating performance recovers from the loss zone to revitalization zone during $\mathrm{CoBO}$ deed/agreement.

Proposition (6b): Consistent operating, and financial prowess notices in the target firm post-CoBO period, if it continues as a single entity.

An interesting study conducted on government initiated venture activity in Australia by Cumming (2007) describes that IIF program provides valuable governance mechanisms to facilitate entrepreneurial finance. ${ }^{31}$ Similar mechanisms observed in the U.S., and advanced to those commenced in Canada, and UK. We define a proposition on target firms controlled by government.

Proposition (7): CoBO policy improves operating performance of government-owned undertakings in the post-buyout period.

In the context of cross-country private equity syndication, Mevleman and Wright (2011) examine the role of institutional context, ${ }^{32}$ and organizational learning ${ }^{33}$ as determinants of cross-border PE syndication. Their results report that institutional context and organizational learning have considerably related to the use of cross-border syndicates. We also recommend their hypothesis to originate propositions, and hypotheses for policy formulation concerning contractual buyout. Hypotheses include why foreign PE firms rely on local partners through cross-border syndicates when investing abroad. We robustly support the hypothesis developed, tested and validated by Mevleman and Wright (2011) that PE firms reduce institutional environment barriers through learning. The following proposition

\footnotetext{
${ }^{31} \mathrm{IIF}$ - Innovation Investment Fund of Australian government program was introduced in 1997.

${ }^{32}$ Institutional context - number of PE firms in the local environment and presence of investment bankers in the local market.

${ }^{33}$ Organizational learning - PE firms experience in the host country, multinational experience, and the number of investment managers per portfolio entity.
} 
depends on the tax subsidization, tax holidays, or any other seminal benefits promised by the respective country.

Proposition (8a): CoBO attracts international VCs and PE firms to invest in loss making units, and government sick industrial clusters.

Proposition (8b): PE firms and VCs increase private and social value by accommodating the debt for sick/loss-making units through $\mathrm{CoBO}$ policy.

\section{Tax savings}

Another motivating avenue, tax savings provide a strong incentive for LBOs. First, by issuing additional debt, firms increase interest deductions. Second, they obtain depreciation benefits. Third, both the principal, and the interest on loans incurred by employee stock ownership plans (ESOPs, if any) are tax deductable (Fox and Marcus, 1992). Vigorously, we also recommend the contributions made by Fox and Marcus, and their subjective propositions greatly suits to explore CoBO propositions. We strongly recommend their proposition 3 - the occurrence of LBOs is positively related to the expected future tax savings (p. 171). The above proposition is suggested to test the hypothesis in $\mathrm{CoBO}$ model by considering various observed variables. Further, we also carry forward their proposition 6 - after the buyout unrelated diversification declines, and proposition 7 - after the buyout, overhead expenses and corporate staff size declines. Similarly, we support the intent developed by Amess and Wright (2012) that smaller LBO deals has motivated to grow their businesses, and swell jobs. We suggest CoBO propositions on acquirer tax savings in light of target firm buyout.

Proposition (9a): Acquirer's free cash flows augment during CoBO deed in the form of commission, or consultancy fees. 
Proposition (9b): Acquirer's free cash flows mount-up after the collapse of CoBO agreement in the form of tax subsidization. ${ }^{34}$

Likewise, Landsman et al. (2002) conduct a test at the individual taxpayer level of associations between compliance rates for capital gains taxes accumulated by RJR Nabisco shareholders during its leveraged buyout. They find non-compliances declining in taxable income, and other interest paid, further it produced more capital gains. Conversely, improved operating results are a cutback in income tax (Bull, 1989). Post-LBO tax savings as a key resource value, because of the heavy debt involved, and the more interest payment required, thus LBOs produce tax shields that can be a major venture for cash flows (Lowenstein, 1985 in [Zahra, 1995]; Opler and Titman, 1991; Roden and Lewellen, 1995). Typically, VCs invest with a view to exit, as entrepreneurial firms do not have cash flows to compensate interest on debt, and dividends on equity, therefore, VCs customarily invest towards an exit, and ensure capital gains (Cumming, 2007).

Proposition (10): CoBO deals do not encroach on acquirer, or target firm retail shareholders tax savings.

\section{Choice of market entry strategy}

We advise multinational VCs, PE players, and investment bankers choose CoBO as a foreign market entry choice in view of international marketing, and cooperative strategies' to avoid biased causes, agency costs (Shivdasani and Wang, 2011), and political risks (Bull, 1989), whilst availing tax benefits by entering contractual deal with loss making units in the host country. Hence, established firms are less risky than brand new firms are. However, new ventures have superior growth and margins, and less survival rates compare to established firms. Further, problems of asymmetric information are more acute in new ventures compare to established firms (Parker and van Praag, 2012). In particular, internationalization exposes

\footnotetext{
${ }^{34}$ Assume that government allowing acquirers to avail tax benefits after completion of contractual buyout deed. Therefore, acquirer would be getting tax benefits in light of CoBO deed.
} 
the firm to a multi-set of prospects, which would permit it to control the possible latent in, and curtail from various asymmetries (Madhok and Keyhani, 2012). ${ }^{35}$

Proposition (11a): CoBO could be a choice of international market entry strategy for acquires at initial stage by investing in established firms (loss, or slow growth firms).

Proposition (11b): CoBO would be superior choice of global market entry strategy for VCs and PE firms in the host country.

After buyout, subsidization of weak units' discontinued and excess cash can be used to create new business, there by promoting entrepreneurship (Jensen, 1989 in [Zahra, 1995]) to promise new life to the loss-making units for economic and industrial integration benefits. Zahra (1993) describes that innovation, and venturing activities stress creating new business through market developments or by undertaking product, process, technological and administrative innovations; one of the venturing goal is to improve productivity and margins. We suggest that these types of venturing are the most welcome in developing nations through cross-country contractual buyouts as a global entry choice. Further, we support the hypothesis developed by Chaganti and Schneer (1994: 245) that performance, and management patterns vary across mode of entry thus does the effectiveness of strategic management patterns. In particular, partial acquisitions help MNEs to protect against sellers ex post opportunism. Therefore, MNEs can form joint ventures with domestic firms by sharing capital, and management of new entities with them, or buying partial equity of established local firms for them (Chen and Hennart, 2004).

Proposition (12): CoBO could be superior inorganic strategy for acquirer's at lesser acquisition cost as a choice of market entry and product diversification. In addition, it lifts acquirer's free cash-flows compared to conventional organic-growth strategies.

\section{Integration strategy and implementation}

\footnotetext{
${ }^{35}$ For example, EMNEs have a history and, thus, experience and expertise in environments characterized by institutional deficits, where regulatory structures are more fickle and less sophisticated.
} 
A firm no longer desire to prolong ownership of a set of actions but wish to continue a market presence. Such a change involves vertical or horizontal de-integration of interests, with retention of one, or more stages in the firms' production process (Wright et al., 1990: 57). Earlier research on $M \& A$ proven that cultural diversity influence socio-culture amalgamation, synergy insight, and shareholder value (Stahl and Voight, 2008) while achieving post-integration planning and administration goals. More importantly, postacquisition process is rarely smooth because in acquiring a new bundle of assets and capabilities, the company also inherits the way in which the target is embedded in its institutional environment (Capron and Guillén, 2009). Hence, the proposed model helps acquirers to gain on-screen experience (Dating-before-Merging) with target firm during CoBO deed. After CoBO deed collapses, if target firm wants to sell their ownership it would be trouble-free task for an acquirer to craft post-acquisition trade operations. Therefore, we explore a proposition in light of post-merger integration as a subjective issue.

Proposition (13): CoBO is an advanced strategy to achieve cross-cultural aspects in domestic M\&A integration. Therefore, it is a better inorganic choice to attain socio, and cross-cultural factors, which are similar to cross-border M\&A integration problems.

\section{Government and policy makers}

In the milieu of political economy, a well-designed policy can change the idiom of the economy that creates country prosperous in-terms of employment, growth, and sustainable economic development. For practitioners and public policy makers, we highlight the need of developing, and enforcing an appropriate regulatory framework that strengthens the principles of fixture under which entrepreneurs drive a paradigm of market for corporate control whilst considering the proposed CoBO model. For example, in the former USSR, the establishment of economic reforms radically changed the commerce and trade activities 
(Filatotchev, Wright, Buck, and Zhukov, 1999). ${ }^{36}$ In particular, post-LBO changes in agency, and governance dealings are another important source of assessment (Zahra, 1995). Interestingly, direct government created venture capital funds in Australia through IIF policy facilitates governing mechanism for entrepreneurial finance (Cumming, 2007). Moreover, the existence, and development of smaller firms are essential for robust economic growth and employment. In the U.S., these firms employ a large amount of people and small businesses are significant innovators in the American economy (Maier and Walker, 1987).

Recently, Siegel et al. (2011) describe that insider information in PE, and LBO transactions suggest a need of adopting regulatory efforts to investigate the acquisition process more closely. Undertaking Maier and Walker (1987) views, we recommend emerging nation's governments to enact $\mathrm{CoBO}$ policy for protecting government control on public sector units, and ensure the promising economic assistance for loss-making industries whilst controlling the monopoly monarch in the competitive business environment. We describe propositions in reference to policymaking, and ratification.

Proposition (14): Robust growth would be observed in small industries, amplification in revenue, and technology transfer due to enactment of CoBO policy.

Proposition (15): Fall in domestic M\&A deals and controlling monopoly character in the trade and commerce due to practice of $\mathrm{CoBO}$ policy. Furthermore, it improves information equilibrium, and transparency between government and industry associations.

In addition to the above policy implications and propositions, further we define CoBO is best-fit tactic, and could be a choice of takeover defensive strategy. In detail, no company, individual, or group of employees (e.g., management buyout) have right to acquire, takeover, or open market purchase of target firm during CoBO deed/agreement period. If outsider convenience acquirer to buy ownership of target firm, thus those types of third party

\footnotetext{
${ }^{36}$ They found that Russian privatized firms have lesser insider stakes, superior external ownership, less worker voice, and better administrative control within the firm than Belarus and Ukraine.
} 
arrangements are void in the court of law. Conversely, it could void CoBO deed, and principles of the model. More importantly, target firm do not have any right to declare management, and administrative changes without consulting acquirer's board. Accordingly, they must follow $\mathrm{CoBO}$ guidelines, and explanations. We explore a proposition in light of defensive tactic.

Proposition (16): $\mathrm{CoBO}$ would be protective strategy against hostile takeovers, and acquisition of outstanding shares in the open market.

\section{CONCLUDING REMARKS}

Surging M\&A and PE deals in emerging market economies influence the regulators that they would be required to continue their public-administrative control in key areas such as public systems, public administration, and focused industries for benefiting the society. This article has presented an original exploration on the academic research grounds ranging from market for corporate control to diversification and partial privatization. We suggest CoBO propositions through considering the distinguished research work contributed in areas such as connection between entrepreneurial activities and firm performance, operating efficiency in the post-LBO period, tax savings, foreign market entry choice through partial acquisition, and the recent studies on international PE syndication, and call for investigating $\mathrm{PE}$ and LBO acquisition process. In particular, we employ the strategies of various buyout models developed in western markets as a pedestal, further initiate to develop new theoretical simulation that is likely to be adopted in emerging and third world nations because of the character of these nation's entrepreneurs, and changing institutional setting in the competitive business environment. More specifically, the motive behind $\mathrm{CoBO}$ deal is equivalent to the theories of merger motives suggested by various famous researchers in the M\&A field (e.g., David and Sim, 1986; a comprehensive review by Trautwein, 1990). Further, we document 
$\mathrm{CoBO}$ as a superior policy framework that promises healthier economic life for declining industries, and attracts foreign investment as a vehicle for economic growth whilst a dynamite to control monopoly trade. Selectively, it promises employment opportunities in small and medium enterprises, which are prosperous channels for country's robust trade, and industry intensification.

Conceptually, contractual buyout is a twofold-secured debt obligation, collective ownership, joint administration, and thereby provides opportunity to buy a target unit in the given period between acquirer, target firm, and financier in the market for corporate control. It shall turns-on while signing an agreement by the parties. Exclusively, it is a takeover defensive tactic, and opportunity to get tax advantage via creating CoBO deal. In particular, CoBO would be efficient inorganic magnetic for international VCs and PEs as a part of foreign market entry strategy. Specifically, CoBO would be best-fit model for cross-border M\&A integration strategy. From the employee perspective, it ensures employability through signing a CoBO deed with sick/loss-making units. Since, it seems to be a futures contract in the capital market; conversely, it regulates unhealthy competition via monitoring monopoly activities.

CoBO propositions are useful in various implications, such as information symmetry and administrative changes, employment and employee role, operating performance and financial arrangement, tax savings, choice of market entry strategy, integration strategy, and government and policy makers. In addition to this, we also describe $\mathrm{CoBO}$ would be takeover defensive strategy, and it can stay away from the economic shocks. In meticulous, we have not been narrow-downed to design subjective and numerical illustrations of the proposed model, and consequences of planning, execution and administration in CoBO deal have been ignored. Therefore, the above two issues are the promising need of contractual buyout model to implement ironically in the industry whilst putting-up in the practice. As a contribution, 
and advancement to theory in the $\mathrm{M} \& \mathrm{~A}$ arena, proposed $\mathrm{CoBO}$ framework shall open the avenues for future research contributors by raising various issues related to that does it differentiates other models. We recommend global VCs, and PEs choose CoBO as investment vehicle to avail the competent business opportunities in both emerging, and budding economies. Promising need of investment in product based industries include auto ancillary, dairy and dairy products, and textile, silk and cotton, likewise services include infrastructure development, state road transportation, and university/higher education. Our inorganic-strategy framework and propositions may also provide some implications for MNE executives, and recommendations for further research. 


\section{References}

Akhigbe A, Madura J, Spencer C. 2004. Partial acquisitions, corporate control, and Performance. Applied Financial Economics 14(12): 847-857.

Allatta JT, Singh H. 2011. Evolving communication patterns in response to an acquisition event. Strategic Management Journal 32(10): 1099-1118.

Amess K, Wright M. 2012. Leveraged buyouts, private equity and jobs. Small Business Economics 38(4): 419-430.

Anand J, Delios A. 2002. Absolute and relative resources as determinants of international acquisitions. Strategic Management Journal 23(2): 119-134.

Ariño A, Ring PS. 2010. The role of fairness in alliance formation. Strategic Management Journal 31(10): 1054-1087.

Axelson U, Strömberg P, Weisbach, MS. 2009. Why are buyouts levered? The financial structure of private equity funds. The Journal of Finance 64(4): 1549-1582.

Balakrishnan S, Koza M. 1993. Information asymmetry, adverse selection and joint ventures: theory and evidence. Journal of Economic Behavior and Organization 20(1): 99-117.

Bouquet C, Birkinshaw J. 2011. How global strategies emerge: an attention perspective. Global Strategy Journal 1(3/4): 243-262.

Bowman E, Singh H, Useem M, Bhadury R. 1999. When does restructuring improve economic performance? California Management Review 41(2): 33-54.

Brannen MY, Voisey CJ. 2012. Global strategy formulation and learning from the field: three modes of comparative learning and a case illustration. Global Strategy Journal 2(1): 51-70.

Braun KM, Latham FS. 2007. The governance of going private transactions - the leveraged buyout board directors as a distinctive source of value. Management Decision 45(5): 866-882.

Braun KM, Latham FS. 2009. Rethinking value creation in leveraged buyouts - board restructuring over the public-private-public cycle. Management Decision 47(5): 702709.

Bruton GD, Ahlstrom D, Wan JCC. 2003. Turnaround in East Asian firms: evidence from ethnic overseas Chinese communities. Strategic Management Journal 24(6): 519-540.

Bull I. 1989. Financial performance of leveraged buyouts: an empirical analysis. Journal of Business Venturing 4(4): 263-279.

Cain MD, Denis DJ, Denis DK. 2011. Earnouts: a study of financial contracting in acquisition agreements. Journal of Accounting and Economics 51(1/2): 151-170.

Capron L, Guillén M. 2009. National corporate governance institutions and post-acquisition target reorganization. Strategic Management Journal 30(8): 803-833.

Chaganti R, Schneer JA. 1994. A study of the impact of owner's mode of entry on venture performance and management patterns. Journal of Business Venturing 9(3): 243-260.

Chakrabarti A, Singh K, Mahmood I. 2007. Diversification and performance: evidence from East Asian firms. Strategic Management Journal 28(2): 101-120.

Chakrabarti A, Vidal E, Mitchell W. 2011. Business transformation in heterogeneous environments: the impact of market development and firm strength on retrenchment and growth reconfiguration. Global Strategy Journal 1(1/2): 6-26.

Chaplinsky S, Niehaus G, Van de Gucht L. 1998. Employee buyouts: causes, structure and consequences. Journal of Financial Economics 48(3): 283-332.

Chen SS, Hennart J. 2004. A hostage theory of joint ventures: why do Japanese investors choose partial over full acquisitions to enter the United States? Journal of Business Research 57(10): 1126-1134. 
CMBOR. 2006. Trends in UK Buyouts, Management buyouts - Quarterly review from CMBOR. Centre for Management Buyouts Research: Nottingham, winter 2006/2007, $1-15$.

Cumming D. 2007. Government policy towards entrepreneurial finance: innovation investment funds. Journal of Business Venturing 22(2): 193-235.

Cumming D, Siegel DS, Wright M. 2007. Private equity, leveraged buyouts and governance. Journal of Corporate Finance 13(4): 439-460.

Cumming DJ. 2005. Agency costs, institutions, learning and taxation in venture capital contracting. Journal of Business Venturing 20(5): 573-622.

Cumming DJ, MacIntosh JG. 2006. Crowding out private equity: Canadian evidence. Journal of Business Venturing 21(5): 569-609.

Dalton DR. 1989. The ubiquitous leveraged buyout (LBO): management buyout or management sellout? Business Horizons 32(4): 36-42.

Damodaran A. 2002. Investment Valuation - Tools and Techniques for determining the value of any asset. John Wiley \& Sons: New York.

David BJ, Sim BS. 1986. Corporate acquisitions - a process perspective. Academy of Management Review 11(1): 145-163.

de la Torre JR, Chacar A. 2012. Network coordination and performance among MNEs in Latin America. Global Strategy Journal 2(1): 3-25.

Drucker PF. 1981. Five rules for successful acquisition. Wall Street Journal Oct 15.

Drummond A. 2012. Research on emerging economies: challenges are always opportunities. Global Strategy Journal 2(1): 48-50.

Elango B, Pattnaik C. 2011. Learning before making the big leap: acquisition strategies of emerging market firms. Management International Review 51(4): 461-481.

Fahrholz B, Loslein R. 1991. Buyouts in Germany. European Management Journal 9(1): 6064.

Filatotchev I, Wright M. 2011. Agency perspectives on corporate governance of multinational enterprises. Journal of Management Studies 48(2): 471-486.

Filatotchev I, Wright M, Buck T, Zhukov V. 1999. Corporate entrepreneurs and privatized firms in Russia, Ukraine and Belarus. Journal of Business Venturing 14(5/6): 475492.

Fishman M. 1989. Pre-emptive bidding and the role of the medium of exchange in acquisitions. The Journal of Finance 44(1): 41-57.

Fjeldstad ØD, Snow CC, Miles RE, Lettl C. 2012. The architecture of collaboration. Strategic Management Journal 33(6): 734-750.

Fox I, Marcus A. 1992. The causes and consequences of leveraged management buyouts. Academy of Management Review 17(1): 62-85.

Govindarajan V, Ramamurti R. 2011. Reverse innovation, emerging markets, and global strategy. Global Strategy Journal 1(3/4): 191-205.

Guo S, Hotchkiss ES, Song W. 2011. Do buyouts (still) create value? The Journal of Finance 66(2): 479-517.

Haleblian J, Devers CE, McNamara G, Carpenter, MA, Davison RB. (2009). Taking stock of what we know about mergers and acquisitions: A review and research agenda. Journal of Management 35(3): 469-502.

Harzing AW. 2002. Acquisitions versus Greenfield investments: international strategy and management of entry modes. Strategic Management Journal 23(3): 211-227.

Hennart JF, Reddy S. 1997. The choice between mergers/acquisitions and joint ventures: the case of Japanese investors in the United States. Strategic Management Journal 18(1): 1-12. 
Howorth C, Westhead P, Wright M. 2004. Buyouts, information asymmetry and the family management dyad. Journal of Business Venturing 19(4): 509-534.

Jensen MC. 1984. Takeovers: folklore and science. Harvard Business Review 62(6): 109-121. Jensen MC. 1989. Eclipse of the public corporation. Harvard Business Review 67(5): 61-74.

Jensen MC, Ruback RS. 1983. The market for corporate control: the scientific evidence. Journal of Financial Economics 11(1/4): 5-50.

Kaplan S. 1989. The effects of management buyouts on operating performance and value. Journal of Financial Economics 24(2): 217-254.

Kaplan SN, Strömberg P. 2009. Leveraged buyouts and private equity. Journal of Economic Perspectives 23(1): 121-146.

Kasparova I. 2007. Financing mergers and acquisitions - specific Russian characteristics. Problems of Economic Transition 50(5): 61-72.

Khandwalla PN. 2002. Effective organizational response by corporates to India's liberalization and globalization. Asia Pacific Journal of Management 19(2/3): 423448.

Kock C, Guillen MF. 2001. Strategy and structure in developing countries: business groups as an evolutionary response to opportunities for unrelated diversification. Industrial and Corporate Change 10(1): 77-113.

Kosedag A, Mehran J, Qian, J. 2009. Reverse-LBOs, re-LBOs and informational asymmetry hypothesis of LBO transactions. Managerial Finance 38(8): 716-728.

Krause SD. 1989. Do small leveraged buyouts add value to the US economy? American Journal of Business 4(2): 7-10.

Lambrecht BM, Myers SC. 2007. A theory of takeovers and disinvestment. The Journal of Finance 62(2): 809-845.

Landsman WR, Shackelford DA, Yetman RJ. 2002. The determinants of capital gains tax compliance: evidence from the RJR Nabisco leveraged buyout. Journal of Public Economics 84(1): 47-74.

Lin $\mathrm{C}, \mathrm{Su}$ D. 2008. Industrial diversification, partial privatization and firm valuation: evidence from publicly listed firms in China. Journal of Corporate Finance 14(4): 405-417.

Lockett A, Wiklund J, Davidsson P, Girma S. 2011. Organic and acquisitive growth: reexamining, testing and extending penrose's growth theory. Journal of Management Studies 48(1): 48-74.

Loh L. 1992. Financial characteristics of leveraged buyouts. Journal of Business Research 24(3): 241-252.

Lowenstein L. 1985. Management buyouts. Columbia Law Review 85(4): 730-784.

Madhok A, Keyhani M. 2012. Acquisitions as entrepreneurship: asymmetries, opportunities, and the internationalization of multinationals from emerging economies. Global Strategy Journal 2(1): 26-40.

Maier II JB, Walker DA. 1987. The role of venture capital in financing small business. Journal of Business Venturing 2(3): 207-214.

Makhija MV. 2004. The value of restructuring in emerging economies: the case of the Czech Republic. Strategic Management Journal 25(3): 243-267.

Malone SC. 1989. Characteristics of smaller company leveraged buyouts. Journal of Business Venturing 4(5): 349-359.

Matusik SF, Fitza MA. 2012. Diversification in the venture capital industry: leveraging knowledge under uncertainty. Strategic Management Journal 33(4): 407-426.

Mevleman M, Wright M. 2011. Cross-border private equity syndication: institutional context and learning. Journal of Business Venturing 26(1): 35-48. 
Meyer KE, Estrin S, Bhaumik SK, Peng MW. 2009. Institutions, resources, and entry strategies in emerging economies. Strategic Management Journal 30(1): 61-80.

Miller DJ. 2006. Technological diversity, related diversification, and firm performance. Strategic Management Journal 27(7): 601-619.

Moschieri C. 2011. The implementation and structuring of divestitures: the unit's perspective. Strategic Management Journal 32(4): 368-401.

Nachum L. 2012. Global comparative strategy. Global Strategy Journal 2(1): 92-95.

Niederkofler M. 1991. The evolution of strategic alliances: opportunities for managerial influence. Journal of Business Venturing 6(4): 237-257.

Oh $\mathrm{CH}$, Contractor FJ. 2012. The role of territorial coverage and product diversification in the multinationality-performance relationship. Global Strategy Journal 2(2): 122-136.

Opler T, Titman S. 1991. The characteristics of leveraged buyout firms (working paper \#991). Anderson Graduate School of Management: University of California, LA.

Opler TC. 1992. Operating performance in leveraged buyouts: evidence from 1985-1989. Financial Management 21(1): 27-34.

Park SH, Russo MV. 1996. When competition eclipses cooperation: an event history analysis of joint venture failure. Management Science 42(6): 875-890.

Parker SC, van Praag CM. 2012. The entrepreneur's mode of entry: business takeover or new venture start? Journal of Business Venturing 27(1): 31-46.

Pe'er A, Gottschalg O. 2011. Red and blue: the relationship between the institutional context and the performance of leveraged buyout investments. Strategic Management Journal 32(12): 1356-1367.

Pehrsson A. 2012. Competition barriers and strategy moderations: Impact on foreign subsidiary performance. Global Strategy Journal 2(2): 137-152.

Peng MW. 2012. The global strategy of emerging multinationals from China. Global Strategy Journal 2(2): 97-107.

Penrose ET. 1959. The Theory of Growth of the Firm. Blackwell: Oxford.

Phan PH, Wright M, Ucbasaran D, Tan WL. 2009. Corporate entrepreneurship: current research and future directions. Journal of Business Venturing 24(3): 197-205.

Prasch RE. 1992. Economics and merger mania: a critique of efficient markets theory. Journal of Economic Issues 26(2): 635-642.

Ragozzino R, Reuer JJ. 2010. The opportunities and challenges of entrepreneurial acquisitions. European Management Review 7(2): 80-90.

Ramamurti R. 2012. What is really different about emerging market multinationals? Global Strategy Journal 2(1): 41-47.

Ray KG. 2010. Mergers and Acquisitions - Strategy, Valuation and Integration. PHI Learning: New Delhi.

Reddy KS. 2015a. Beating the Odds! Build theory from emerging markets phenomenon and the emergence of case study research - A "Test-Tube" typology. Cogent Business \& Management 2(1): in press.

Reddy KS. 2015b. Determinants of cross-border mergers and acquisitions: A comprehensive review and future direction (paper in progress).

Reddy KS. 2015c. Extant reviews on entry-mode/internationalization, mergers \& acquisitions, and diversification: Understanding theories and establishing interdisciplinary research. Retrieved from http://mpra.ub.unimuenchen.de/63744/1/MPRA_paper_63744.pdf.

Reddy KS. 2015d. Revisiting and reinforcing the Farmers Fox theory: A study (test) of three cases in cross-border inbound acquisitions. Retrieved from http://mpra.ub.unimuenchen.de/63561/1/MPRA_paper_63561.pdf. 
Reddy KS, Nangia VK, Agrawal R. 2014a. Farmers Fox Theory: does a country's weak regulatory system benefit both the acquirer and the target firm? Evidence from Vodafone-Hutchison deal. International Strategic Management Review 2(1): 56-67.

Reddy KS, Nangia VK, Agrawal R. 2014b. The 2007-2008 global financial crisis, and crossborder mergers and acquisitions: A 26-nation exploratory study. Global Journal of Emerging Market Economies 6(3): 257-281.

Robbie K, Wright M, Ennew C. 1993. Management buy-outs from receivership. Omega 21(5): 519-529.

Robbie K, Wright M, Thompson S. 1992. Management buy-ins in the UK. Omega 20(4): 445-456.

Robbins DK, Pearce JA. 1992. Turnaround: retrenchment and recovery. Strategic Management Journal 13(4): 287-309.

Roden DM, Lewellen WG. 1995. Corporate capital structure decisions: evidence from leveraged buyouts. Financial Management 24(2): 76-87.

Schlingemann FP. 2004. Financing decisions and bidder gains. Journal of Corporate Finance 10(5): 683-701.

Shivdasani A, Wang Y. 2011. Did structured credit fuel the LBO boom? The Journal of Finance 66(4): 1291-1328.

Shrieves RE, Pashley MM. 1984. Evidence on the association between mergers and capital structure. Financial Management 13(3): 39-48.

Siegel D, Wright M, Filatotchev I. 2011. Private equity, LBOs and corporate governance: international evidence. Corporate Governance: An International Review 19(3): 185194.

Simsek Z, Heavey C. 2011. The mediating role of knowledge-based capital for corporate entrepreneurship effects on performance: a study of small to medium-sized firms. Strategic Entrepreneurship Journal 5(1): 81-100.

Slangen AHL. 2011. A communication-based theory of the choice between Greenfield and acquisition entry. Journal of Management Studies 48(8): 1699-1726.

Slovin MB, Sushka ME, Polonchek JA. 2005. Methods of payment in asset sales: contracting with equity versus cash. The Journal of Finance 60(5): 2385-2407.

Stahl GK, Voight A. 2008. Do cultural differences matter in mergers and acquisitions? a tentative model for examination. Organization Science 19(1): 160-176.

Su D. 2005. Corporate Finance and State enterprise reform in China. China Economic Review 16(2): 118-148.

Thronhill S, Amit R. 2000. A dynamic perspective of international fit in corporate venturing. Journal of Business Venturing 16(1): 25-50.

Trautwein F. 1990. Merger motives and merger perceptions. Strategic Management Journal 11(4): 283-295.

UNCTAD 2009. World Investment Report 2009: Transnational corporations, agriculture production and development. United Nations Conference on Trade and Development: Geneva, Switzerland.

UNCTAD 2010. World Investment Report 2010: Investing in a low-carbon economy. United Nations Conference on Trade and Development: Geneva, Switzerland.

Ushijima T. 2010. Understanding partial mergers in Japan. Journal of Banking \& Finance 34(12): 2941-2953.

Valentini G. 2012. Measuring the effect of M\&A on patenting quantity and quality. Strategic Management Journal 33(3): 336-346.

Villalonga B, Mcgahan AM. 2005. The choice among acquisitions, alliances, and divestitures. Strategic Management Journal 26(13): 1183-1208. 
Wang L, Zajac EJ. 2007. Alliance or acquisition? a dyadic perspective on interfirm resource combinations. Strategic Management Journal 28(13): 1291-1317.

Weir CM, Lating D, Wright M. 2005. Incentive effects monitoring mechanisms and the market for corporate control. Journal of Business Finance and Accounting, 32(5/6): 909-943.

Westney DE. 2011. Global strategy and global business environment: changing models of the global business environment. Global Strategy Journal 1(3/4): 377-381.

Weston JF, Chung KS, Hoag SE. 1998. Mergers, Restructuring and Corporate control (2nd edn). Prentice Hall: New Delhi.

Wiersema MF, Liebeskind JP. 1995. The effect of leveraged buyouts on corporate growth and diversification in large firms. Strategic Management Journal 16(6): 447-460.

Wright M, Buck T. 1992. Employee buyouts and privatization: issues and implications for LDCs and post communist countries of UK experience. Public Administration and Development 12(3): 279-296.

Wright M, Chiplin B, Thompson S, Robbie K. 1990. Management buy-outs and large-small firm relationships. Management International Review 30(1): 55-72.

Wright M, Filatotchev I, Buck T. 1993. The role of buyouts in restructuring Central and Eastern Europe: theory and practice. International Business Review 2(3): 239-252.

Wright M, Hoskisson RE, Busenitz L, Dial J. 2000. Entrepreneurial growth through privatization: the upside of management buyouts. Academy of Management Review 25(3): 591-601.

Wright M, Kitamura M, Hoskisson RE. 2003. Management buyouts and restructuring Japanese corporations. Long Range Planning 36(4): 355-373.

Wright M, Lockett A. 2003. The structure and management of alliances: syndication in the venture capital industry. Journal of Management Studies 40(8): 2073-2104.

Wright M, Robbie K, Thompson S. 1989. On the finance and accounting implications of management buyouts. British Accounting Review 21(3): 219-235.

Wright M, Thompson S, Robbie K. 1992. Venture capital and management-led, leveraged buyouts: a European perspective. Journal of Business Venturing 7(1): 47-71.

Wright M, Thompson S, Robbie K, Starkey K. 1994. Longevity and the life cycle of management buyouts. Strategic Management Journal 15(3): 215-217.

Wright P, Kroll M, Lado A, Ness BV. 2002. The structure of ownership and corporate acquisition strategies. Strategic Management Journal 23(1): 41-53.

Zahra SA. 1991. Predictors and outcomes of corporate entrepreneurship: an exploratory study. Journal of Business Venturing 6(4): 259-285.

Zahra SA. 1993. Environment, corporate entrepreneurship and financial performance: a taxonomic approach. Journal of Business Venturing 8(4): 319-340.

Zahra SA. 1995. Corporate entrepreneurship and financial performance: the case of management leveraged buyouts. Journal of Business Venturing 10(3): 225-247.

Zahra SA, Filatotchev I, Wright M. 2009. How do threshold firms sustain corporate entrepreneurship? the role of boards and absorptive capacity. Journal of Business Venturing 24(3): 248-260. 


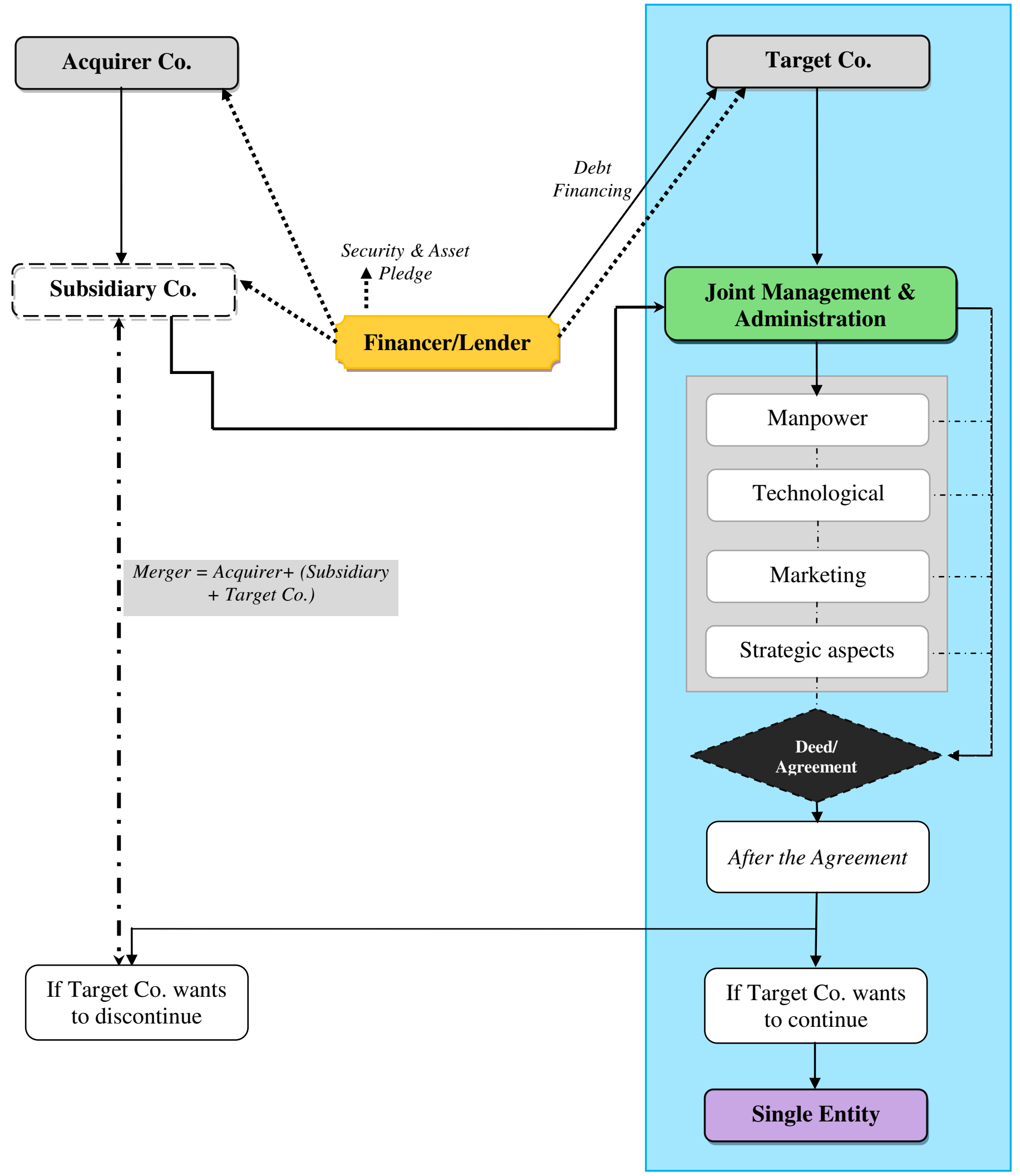

Fig 1. Contractual Buyout (CoBO) model 


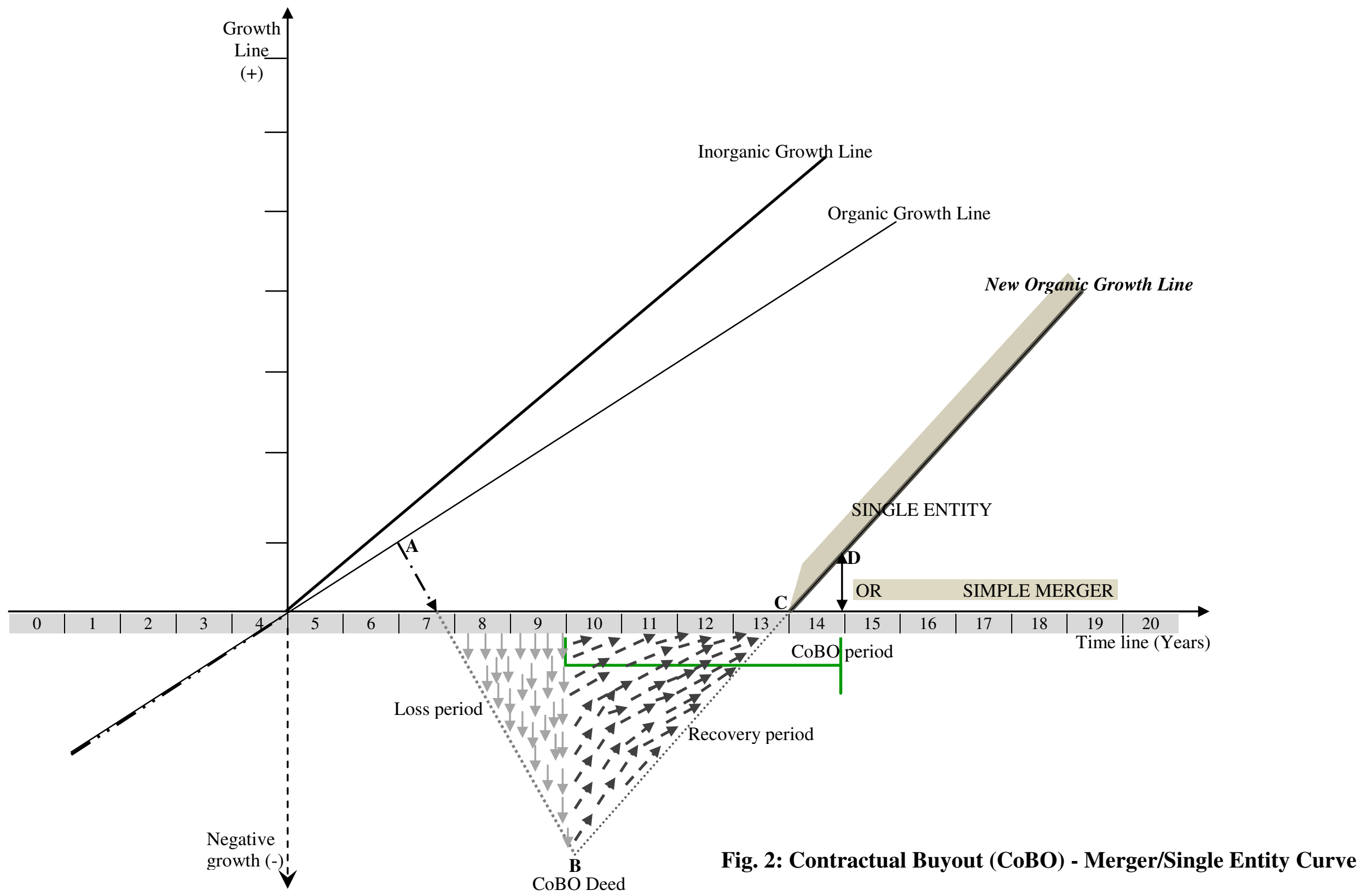




\section{FOUNDATIONS TO THE MODEL}

Jensen \& Ruback

(1983)

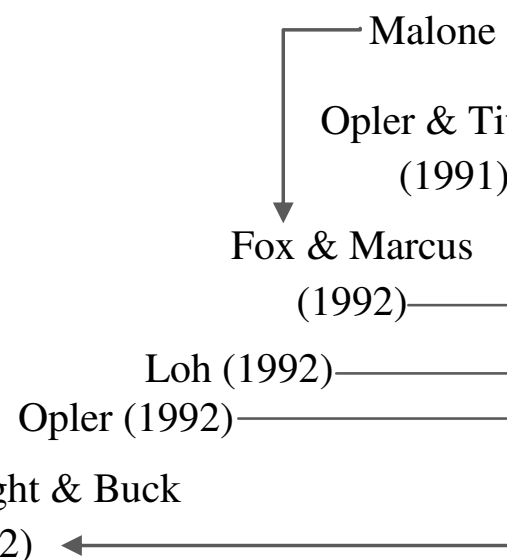

(1992)

Wright et al.

(1993)

Wright et al.

(1994)

Bowman et al.

(1999)

Wright et al.

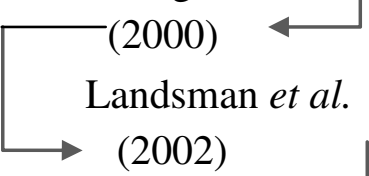

Wright et al. (2003)

$\checkmark$ Chen \& Hennart (2004)

Weir et al. (2005)

Kasparova (2007)

$\longrightarrow$ Lin \& Su (2008)

$\longrightarrow$ Guo et al. (2011)

Ushijima (2010)

Shivdasani \& Wang (2011) $\gg$ Ramamurti (2012)

\section{POLICY IMPLICATIONS}

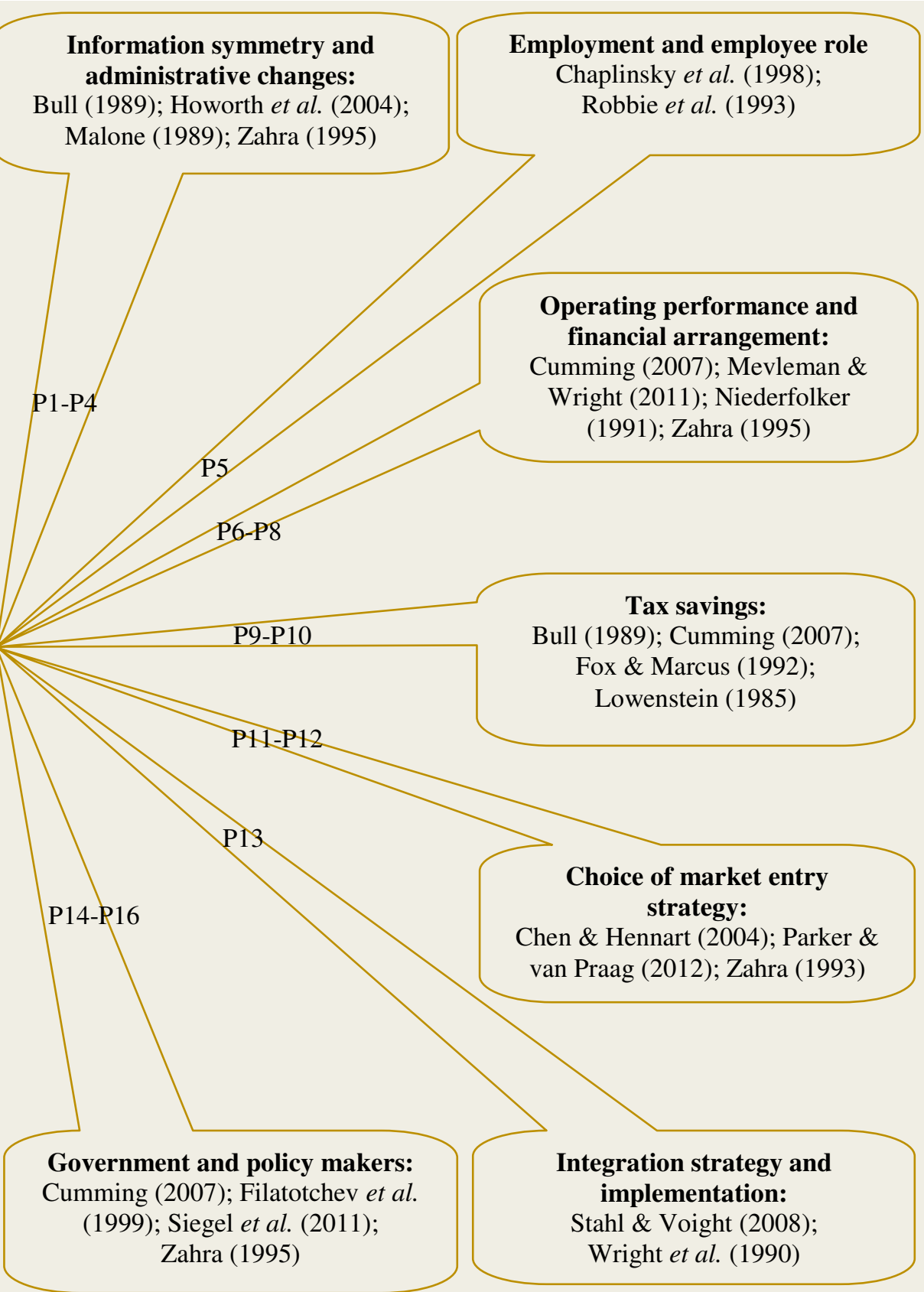

Fig. 3: Contractual Buyout (CoBO): Foundations and Policy implications

Note: P- represents Proposition

\section{CONTRACTUAL BUYOUT} (CoBO)

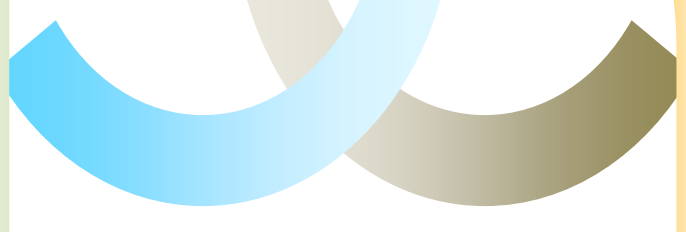

